\title{
Variation in wood volatile compounds in a mixed oak stand: strong species and spatial differentiation in whisky-lactone content
}

\author{
Andrei PRIDA ${ }^{\mathrm{a}}$, Alexis DUCOUSso ${ }^{\mathrm{b}}$, Rémy J. PETIT ${ }^{\mathrm{b}}$, Gérard NEPVEU $^{\mathrm{c}}, \mathrm{Jean}^{-L o u i s}$ PUECH $^{\mathrm{a} *}$ \\ a Unité Mixte de Recherche "Science pour l'Enologie", INRA, 2 place Viala, 34060 Montpellier, France \\ ${ }^{\mathrm{b}}$ UMR BIOGECO, INRA, 69 route d'Arcachon, 33612 Cestas Cedex, France \\ ${ }^{c}$ LERFoB (Laboratoire d’Étude des Ressources Forêt-Bois, INRA-Engref), Centre INRA de Nancy, 54280 Champenoux, France
}

(Received 5 May 2006; accepted 4 October 2006)

\begin{abstract}
The effect of species and ecological conditions on oak volatile extractive content was investigated in an evenaged (100 years) stand located in western France. The sample included a total of 286 trees (118 sessile, 158 pedunculate and 10 oaks with an intermediate morphology) growing in contrasted environments (plateau, intermediate slope, small valley). The main factor influencing oak extractives level is species. The effect of the local environment appears negligible. No correlation between ring width and volatile extractive content was found. Q. petraea is significantly richer than $Q$. robur in eugenol and whisky-lactone (10.8 vs. $0.6 \mu \mathrm{g} / \mathrm{g})$. However, two groups of sessile oaks could be identified, one poor and one rich in whisky-lactone. Among the latter, either the cis or the trans stereoisomer was predominant, suggesting that their production is not independent. A strong spatial structure was detected for whisky-lactone (cis-, trans- and total whisky-lactone, for the two species combined but also for $Q$. petraea alone in the case of the cis isomer).
\end{abstract}

volatile compounds / oak wood / Quercus robur L. / Quercus petraea Liebl. / within-stand variability / ecological conditions

\begin{abstract}
Résumé - Variation des composés volatils du bois dans un peuplement mixte de chênes : forte différenciation interspécifique et forte structuration spatiale de la quantité de whisky-lactone. Les effets de l'espèce de chêne et des conditions écologiques locales sur les teneurs en composés volatils ont été étudiés dans un peuplement équienne (100 ans) situé dans l'ouest de la France. L'échantillon total inclut 286 arbres (118 chênes sessiles, 158 chênes pédonculés et 10 chênes intermédiaires) répartis en mélange dans trois zones écologiques du peuplement (plateau, pente et fond de vallon). Le facteur principal qui influence la teneur en extractible du bois de chêne est l'espèce botanique. L'effet environnement apparaît négligeable et il n'existe aucune relation entre la largeur de cerne et les substances volatiles. Le bois de chêne sessile $(Q$. petraea) possède des teneurs plus élevées que le chêne pédonculé $(Q$. robur) en eugénol et en whisky-lactone $(10,8 \mu \mathrm{g} / \mathrm{g}$ contre $0,6 \mu \mathrm{g} / \mathrm{g})$. Cependant, les chênes sessiles se divisent en deux groupes, l'un pauvre en whisky-lactone et l'autre riche en ce composé. Parmi ce dernier groupe, on observe que l'une des deux formes stéréoisomères (cis ou trans) prédomine, suggérant que leur biosynthèse n'est pas indépendante. On constate enfin une forte structuration spatiale pour les whisky-lactones pour les deux espèces combinées mais également chez Q. petraea seul pour l'isomère cis.
\end{abstract}

composés volatils / bois de chêne / Quercus robur L. / Quercus petraea Liebl. / variabilité intrapeuplement / conditions écologiques

\section{INTRODUCTION}

Volatile extractive compounds of cooperage oak wood play an essential role in wine and spirits maturation in oak casks. They generally have low aroma thresholds so that their sensorial detection takes place at very low concentration in mature beverages $[1,5,8,19]$. They are responsible for important olfactory notes such as coconut, woody, vanilla, caramel etc. Volatile substances content is strongly affected by natural factors as well as by cooperage techniques: seasoning $[5,9,15,16,30,34]$ and toasting $[6,10]$. Among the natural factors that have been cited are botanical species and local environment, both of which can affect growth (and hence 'grain' = ring width). The 'grain' is often considered to be related with chemical composition of oak wood and used for wood selection by coopers. Oak wood with a wide grain is generally expected to have a low

* Corresponding author: puechj1@ensam.inra.fr content of volatile substances and a high proportion of total extract and ellagitannins, whereas narrow grain is typically associated with oak wood rich in volatile substances and poor in tannins [17, 18, 36, 37]. However, these generalisations have recently been questioned $[7,18]$. In particular, Mosedale et al. [25] have demonstrated that ring width is independent of ellagitannins amount. Several research groups have investigated the botanical species (Quercus robur L. and Quercus petraea Liebl.) in relation to climate, topography, soil and dendrology $[4,13,20,32,33]$. These species are known to differ in the concentration of some volatile substances, especially the $\beta$-methyl- $\gamma$-octolactone (whisky-lactone), which was consistently found to be more abundant in $Q$. petraea than in $Q$. robur $[8,14,18,26-28]$.

Other volatiles were found to differ according to botanical species or to geographical origin. Chatonnet et al. [9] and Snakkers et al. [35] found that eugenol content varies among French forests (Limousin, Vosges, Bourgogne, and Centre). Vivas et al. [37] have observed higher levels of vanillin and 

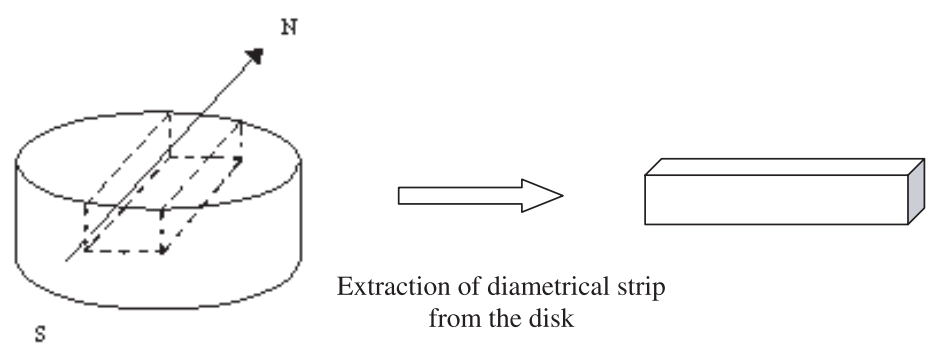

Extraction of diametrical strip

from the disk

$10 \mathrm{~cm}$ width disk cut up at the

$1.30 \mathrm{~m}$ height of the trunk

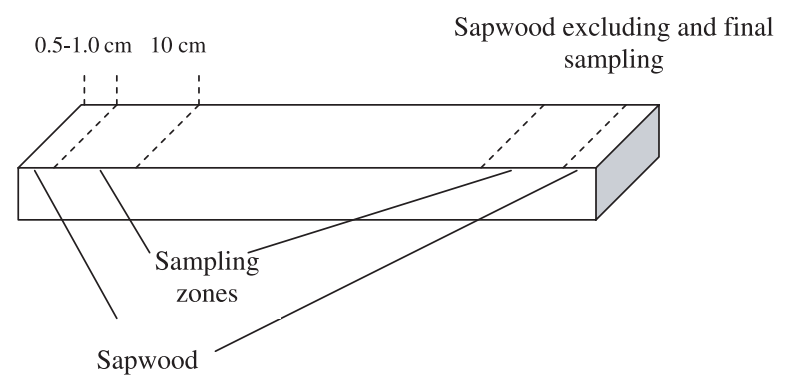

Figure 1. Sampling of wood for the chemical analyses.

lower levels of whisky-lactone and eugenol for eastern European woods of both species in comparison with French oaks of the same species. Doussot [15], on the basis of a large sample of oaks from French and Spanish forests, concludes that both environment and botanical species determines volatile extractive content in oak wood.

In such research the high natural variability of volatiles in oak wood within and between individual trees must be taken into consideration. Moreover, experimental practices such as sampling, storage and preparation could affect analytical results and compromise the study. It is therefore necessary to use a large sample set as well as similar sampling procedures and experimental conditions.

The aim of the current study is to clarify the influence of botanical species, ring width and local environment on the composition in volatile compounds of oak heartwood. The studied population is an evenaged mixed oak stand. All constitutive trees were sampled; they are $\sim 100$ years from seed and have grown under similar silvicultural conditions. The trees are distributed in three contrasted ecological zones (valley, hill and intermediary level), allowing a detailed investigation of both species and local environmental effects.

\section{MATERIALS AND METHODS}

\subsection{Wood sampling}

The sampled stand (French Department Sarthe, La Petite Charnie State Forest, latitude: $48.08^{\circ} \mathrm{N}$, longitude: $0.17^{\circ} \mathrm{W}$ ) is located in the western part of France [2,31]. The stand is included in a continuous forest of 700 ha, consisting mostly of naturally regenerated mixed stands of $Q$. petraea and $Q$. robur. The sampled stand covers approximately 5 ha with a total of 286 standing trees. It consists of three ecological zones: a small valley, a plateau and a regular intermediate slope. The plateau is covered by a well drained soil and composed of sand and slit. The small valley is characterized by humid clayish soil. There is a significant correlation between oak species distribution and soil type and elevation. The natural regeneration of this stand from seeds took place in 1899-1900, as assessed by ring counting. During the autumns 1998, 2000 and 2001 all the trees were cut. Thus all the trees under investigation were approximately of the same age (100 years). The species was identified using Factorial Discriminant Analysis on 34 leaf markers [2]. A total of 286 trees (118 Q. petraea, $158 Q$. robur and 10 intermediate oaks) were used in this study. The species distribution between zones is as follows: $Q$. robur (plateau: 17 , intermediate slope: 57 , small valley 84 trees), Q. petraea (plateau: 52, intermediate slope: 62, small valley: 4 trees), intermediate oaks (plateau: 2, intermediate slope: 2, small valley: 6 trees).

For each oak tree a $10 \mathrm{~cm}$ thick disk was cut at $1.30 \mathrm{~m}$. From this disk a $10 \mathrm{~cm}$ wide strip oriented North-South (from bark to bark) was extracted through sawing. Sapwood was excluded by relying on the colour of the wood sample. Final sampling was carried out by shaving two $10 \mathrm{~cm}$ zones of heartwood (approximately 35-40 rings) located on both sides of each diametric strip (Fig. 1). The wood shavings were mixed in order to obtain one powdered sample per tree, with linear dimensions equal or smaller than $0.5 \mathrm{~mm}$. Newly felled trees were used and all the procedures were performed identically for all trees. Each sample consisted of the powder from an individual tree and all the samples were analysed separately. The aforementioned $10 \mathrm{~cm}$ zones were used for visual calculation of ring numbers, which were transformed afterwards in average ring width expressed in $\mathrm{mm}$.

\subsection{Chemical analyses}

The sawdust samples $(10 \mathrm{~g})$ were extracted in bulk with $100 \mathrm{~mL}$ of dichloromethane (pesticide analysis quality) for $18 \mathrm{~h}$ at room temperature under magnetic stirring. According to a preliminary test 
such procedure results in the extraction of $85-100 \%$ of the studied compounds in liquid medium. These values are obtained by comparison of the amount of volatile substance extracted by aforementioned method and the sum of amounts extracted within three repeated 18-h extractions, that are considered exhaustive. After circa 50 times concentration of the extract under vacuum (concentration from about $100 \mathrm{~mL}$ to $1.5-2 \mathrm{~mL}$ of the sample volume), internal standard (4-nonanol solution in dichloromethane $1 \mathrm{mg} / \mathrm{mL}$ ) was added to each sample to control the volume of the chromatographic injection.

The GC/MS process was carried out using equipment from Hewlett-Packard: HP 6890 Series GC System, HP 5973 Mass Selective Detector, GC AutoSampler Controller, Aglient 6890 Series Injector and controlled by HP ChemStation software (version A.03.00). Samples were chromatographed on a DB-WAX column $(30 \mathrm{~m} \times$ $320 \mu \mathrm{m}, 0.5 \mu \mathrm{m}$ thickness). Temperature was held at $60^{\circ} \mathrm{C}$ for $3 \mathrm{~min}$ and then increased per $4{ }^{\circ} \mathrm{C}$ a min until it reached $238^{\circ} \mathrm{C}$. The carrier gas was helium with a constant flow of $1 \mathrm{ml} / \mathrm{min}$. Injection volume $1 \mu \mathrm{L}$. MS spectra were obtained at $70 \mathrm{eV}$, with the mass range scanned from 40 to $500 \mathrm{amu}$.

Identification was performed by mass-spectrometry using the Willey database and by co-chromatography with pure reference substances. Quantification was carried out by integration of characteristic ions peaks (whisky-lactone $\mathrm{m} / \mathrm{z}=99 ; 2$-phenylethanol $\mathrm{m} / \mathrm{z}=91$; pantolactone $\mathrm{m} / \mathrm{z}=71$; eugenol $\mathrm{m} / \mathrm{z}=164$; mevalonic lactone $\mathrm{m} / \mathrm{z}=$ 71 ; vanillin $\mathrm{m} / \mathrm{z}=151$; , syringaldehyde $\mathrm{m} / \mathrm{z}=182$, coniferaldehyde $\mathrm{m} / \mathrm{z}=178$ ). The method was calibrated using triplicate injections of a series of external standards for each quantified substance. Reference substances for calibration were supplied by Sigma-Aldrich. All results were expressed in $\mu \mathrm{g} / \mathrm{g}$ recalculated on oven-dry wood mass obtained by oven drying of sample at $105^{\circ} \mathrm{C}$ for $4 \mathrm{~h}$.

\subsection{Data analyses}

\subsubsection{Comparisons across sets}

The traits investigated were the amounts of the nine principal oak volatile substances, total whisky-lactone and the proportion of cis whisky-lactone, as well as ring width. Several volatile compounds present either low concentration or much higher values across trees, resulting in non-normal distribution; log-transformation was not sufficient to normalise these distributions, so non-parametric tests were used throughout. We used SYSTAT 10.2 for most statistical analyses. First, species effects were investigated with a Kruskal-Wallis test, the nonparametric analogue to a one-way analysis of variance. For each species, differences between ecological zones were tested with the same procedure. In this case, the samples of intermediate morphology were excluded because of limited sample size (10 trees).

\subsubsection{Correlation analysis}

To investigate relations between variables, Spearman rank-order correlation coefficients, which are based on the ranks of the data rather than on the actual values, were used.

\subsubsection{Spatial analysis}

We have used the SGS software [11]. The spatial structure of continuous quantitative traits can be analysed by applying a distance measure. The mean distance between all pairs of individuals belonging to a given distance class serves as the measure of spatial structure. The mean over all pairs provides the reference value indicating absence of spatial structure. Values below the reference show positive autocorrelation and those higher indicate negative spatial autocorrelation. The SGS program computes transformed values of each trait using the $z$-transformation. This transformation is necessary to avoid problems with changing scales among different traits $[11,12]$. The aggregate size is determined when the distance curve intercepts the mean line.

\section{RESULTS}

The values of volatile compounds content in oak wood obtained by chemical analysis were comparable with results obtained by other authors for European oak wood [28,29]. As in these papers, a high individual variability of wood extractives was observed. Nevertheless, some important new insights concerning their variation were obtained.

\subsection{Species differentiation}

For six of the nine volatile compounds, no significant difference between species was detected (Tab. I). However, higher amounts of eugenol and whisky-lactones (both cis and trans isomers) are present in $Q$. petraea than in $Q$. robur. The difference is especially marked for whisky-lactone, with $Q$. petraea having 20 times more cis whisky-lactone (6.90 vs. $0.34 \mu \mathrm{g} / \mathrm{g}$ of oven-dry wood) and 12 times more trans whisky-lactone (3.88 vs. $0.28 \mu \mathrm{g} / \mathrm{g}$ of oven-dry wood) than $Q$. robur. The proportion of cis whisky-lactone was also slightly but highly significantly higher in $Q$. petraea (0.66 vs. 0.58 ), which had also slightly larger ring width than $Q$. robur (2.83 vs. $2.52 \mathrm{~mm})$. By contrast, for both species, no difference between ecological zones was identified for any of the trait (Tab. I).

Differences between whisky-lactone content between species were further analysed. The overall distribution in total whisky-lactone concentration is clearly bimodal (Fig. 2a), with a first peak at $0.2-0.3 \mu \mathrm{g} / \mathrm{g}$ of oven-dry wood (i.e., trace amounts), and a second one at $10-15 \mu \mathrm{g} / \mathrm{g}$. The first peak corresponds to the vast majority of the $Q$. robur trees but also to a non-negligible proportion of trees identified as $Q$. petraea. Actually, the distribution of whisky-lactone concentration is bimodal in $Q$. petraea (Fig. 2b). As shown in Figure 3 , the proportion of cis whisky-lactone is slightly higher than the proportion of trans whisky-lactone in both species. However, there is a difference among individuals regarding the proportion of the cis isomer: it is clearly bimodal in individuals that have high levels of whisky-lactone (i.e. mostly $Q$. petraea), contrary to what is found in individuals with only trace amounts of whisky-lactone (Fig. 3). In other words, oaks with high amounts of whisky-lactone are either clearly richer in the cis isomer (in $\sim 2 / 3$ of the trees) or in trans isomer $(\sim 1 / 3)$, whereas oaks withg only trace amounts of whiskylactone typically have balanced amounts of the two isomeres. Finally, trees with an intermediate morphology had generally low amounts of whisky-lactone (9 of 10; see Fig. 3). 
Table I. Comparison of wood volatile compounds and ring width between $Q$. robur and $Q$. petraea as well as between the three ecological zones (plateau, intermediate slope, small valley) in each species.

\begin{tabular}{|c|c|c|c|c|c|}
\hline & Q. petraea & Q. robur & & Test $^{1}$ & \\
\hline Trait & $\begin{array}{c}\text { Mean }(\mathrm{std}), \mu \mathrm{g} / \mathrm{g} \text { of } \\
\text { oven-dry wood }\end{array}$ & $\begin{array}{c}\text { Mean (std), } \mu \mathrm{g} / \mathrm{g} \text { of } \\
\text { oven-dry wood }\end{array}$ & Species effect & $\begin{array}{l}\text { Environmental effect } \\
\quad \text { for } Q . \text { petraea }\end{array}$ & $\begin{array}{l}\text { Environmental effect } \\
\text { for } Q . \text { robur }\end{array}$ \\
\hline 2-phenylethanol & $\begin{array}{c}0.14 \\
(0.08)\end{array}$ & $\begin{array}{c}0.16 \\
(0.13)\end{array}$ & 0.524 & 0.27 & 0.14 \\
\hline Pantolactone & $\begin{array}{l}0.22 \\
(0.13)\end{array}$ & $\begin{array}{l}0.25 \\
(0.16)\end{array}$ & 0.239 & 0.17 & 0.45 \\
\hline Eugenol & $\begin{array}{c}0.58 \\
(0.69)\end{array}$ & $\begin{array}{l}0.30 \\
(0.30)\end{array}$ & 0.001 & 0.08 & 0.62 \\
\hline Mevalonolactone & $\begin{array}{c}1.02 \\
(0.75)\end{array}$ & $\begin{array}{c}0.88 \\
(0.54)\end{array}$ & 0.416 & 0.25 & 0.06 \\
\hline Vanillin & $\begin{array}{c}3.16 \\
(1.60)\end{array}$ & $\begin{array}{c}3.79 \\
(1.99)\end{array}$ & 0.051 & 0.22 & 0.48 \\
\hline Syringaldehyde & $\begin{array}{l}5.68 \\
(2.78)\end{array}$ & $\begin{array}{c}6.62 \\
(3.49)\end{array}$ & 0.075 & 0.06 & 0.92 \\
\hline Coniferaldehyde & $\begin{array}{c}2.80 \\
(2.01)\end{array}$ & $\begin{array}{c}3.44 \\
(2.63)\end{array}$ & 0.352 & 0.40 & 0.55 \\
\hline cis whisky-lactone & $\begin{array}{r}6.90 \\
(7.53)\end{array}$ & $\begin{array}{c}0.34 \\
(1.09)\end{array}$ & $<0.001$ & 0.57 & 0.12 \\
\hline trans whisky-lactone & $\begin{array}{c}3.88 \\
(6.41)\end{array}$ & $\begin{array}{c}0.28 \\
(0.92)\end{array}$ & $<0.001$ & 0.65 & 0.05 \\
\hline Total whisky-lactone & $\begin{array}{c}10.78 \\
(10.38)\end{array}$ & $\begin{array}{c}0.61 \\
(1.60)\end{array}$ & $<0.001$ & 0.54 & 0.06 \\
\hline Ratio cis/total & $\begin{array}{c}0.66 \\
(0.26)\end{array}$ & $\begin{array}{c}0.58 \\
(0.18)\end{array}$ & $<0.001$ & 0.59 & 0.98 \\
\hline Ring width & $\begin{array}{c}2.83 \\
(0.48)\end{array}$ & $\begin{array}{c}2.52 \\
(0.38)\end{array}$ & $<0.001$ & 0.78 & 0.07 \\
\hline
\end{tabular}

${ }^{1}$ Comparison based on ranks ( $P$-value, Kruskall-Wallis test); due to multiple tests, only values below 0.01 are considered significant.

\subsection{Correlation between studied traits}

Interdependence between traits was investigated by nonparametric correlations (Tab. II). Ring width is only weakly related with the abundance of volatile compounds. Mevalonolactone also varies largely independently of all other investigated traits. The proportion of cis whisky-lactone in the total whisky-lactone is poorly related to all traits except $\mathrm{cis}$ whisky-lactone content. On the contrary, several strong relationships were identified between the remaining traits. Two groups of volatile compounds covary rather closely $\left(r_{\mathrm{S}}>0.8\right)$ : cis- and trans whisky-lactones on the one hand, and vanillin, syringaldehyde and coniferaldehyde on the other hand. These last three compounds all belong to the lignin-shikimate pathway [21]. Along with eugenol and 2-phenylethanol, these compounds are clearly correlated with each other $\left(r_{\mathrm{S}} \sim 0.6\right)$, whereas pantolactone is somewhat less correlated with these five compounds $\left(r_{\mathrm{S}} \sim 0.3-0.4\right)$.

\subsection{Spatial structure}

A weak spatial structure was detected for 2-phenylethanol (in $Q$. petraea) and a strong one for whisky-lactone (cis-, trans- and total whisky-lactone, for the two species combined but also for $Q$. petraea in the case of the cis isomer) (Tab. III). A map of the distribution of cis whisky-lactone content among trees of the stand is shown (Fig. 4). The spatial organisation of the two species combined with their clear differentiation in whisky-lactone content explain the clear overall spatial structure, but a clustering can also be observed within $Q$. petraea (Figs. 4a, 5).

\section{DISCUSSION}

The large number of trees investigated (286 individuals from a single stand) has allowed the most detailed study to date 


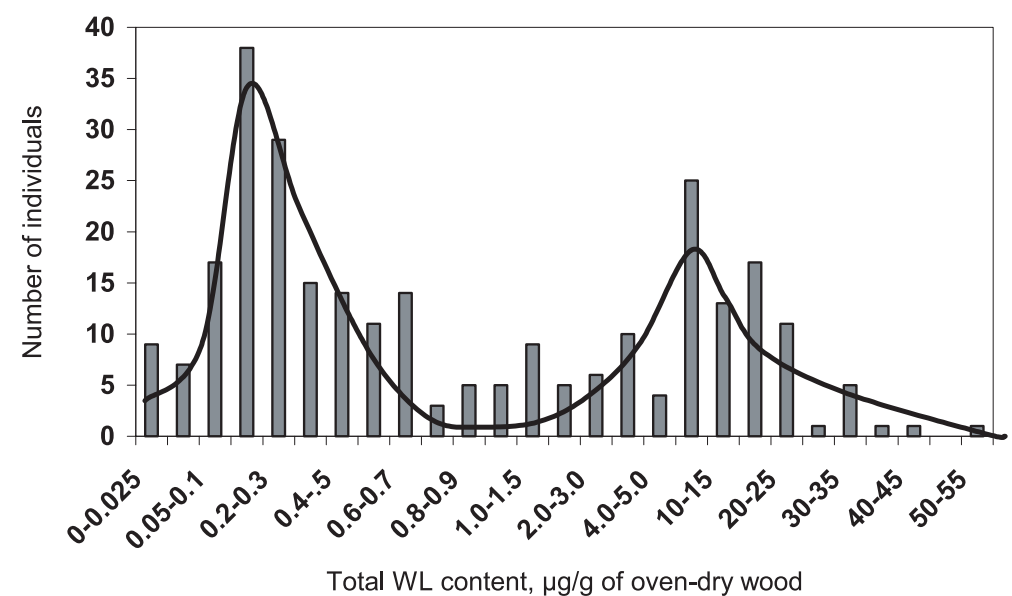

(a)

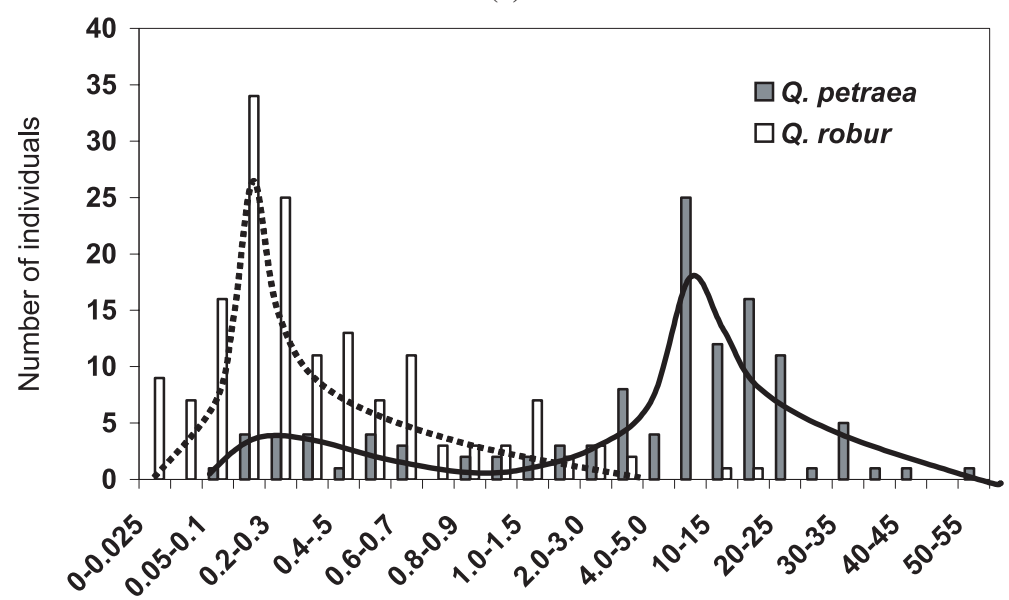

Total WL content, $\mu \mathrm{g} / \mathrm{g}$ of oven-dry wood

(b)

Figure 2. (a) Distribution of total whisky-lactone content in the overall set (both species - 276 samples, without intermediate oaks). (b) Distribution of total whisky-lactone content in each species (118 sessile oaks, 158 pedunculate oaks).

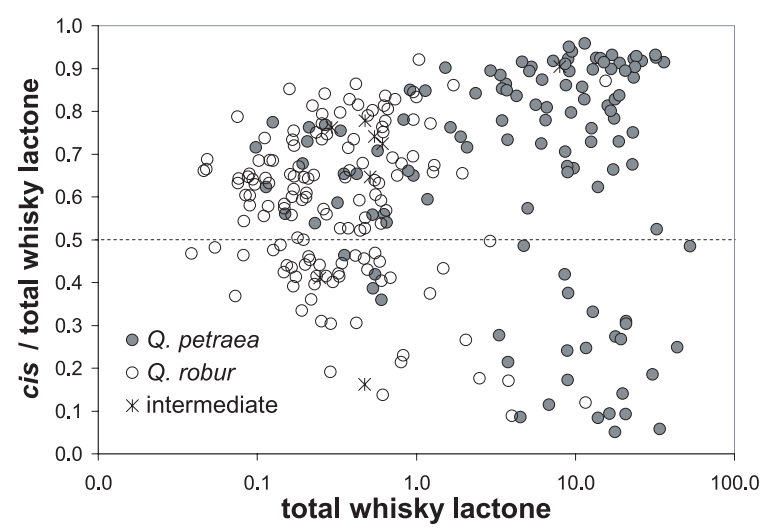

Figure 3. Proportion of cis whisky-lactone as a function of total whisky-lactone.

of the variation in wood volatile compounds of the two European oaks used by the barrel industry to age wines and alco- hols. The only factor found to influence at least some of these volatile compounds is botanical species. Its effect is particularly strong for whisky-lactone. By contrast, no indication was found that the local environment (ecological zones, as defined in previous careful ecological surveys of the stand) affects the amount of any volatile compounds. Furthermore, mean ring width, an index of the local environment of the trees, shows no relation with any volatile compound. These results suggest that the difference found between the two species has a genetic basis since it does not seem to interact with ecological conditions.

The bimodal distribution of whisky-lactone content among trees is remarkable and is also suggestive of a simple genetic basis. Introgression between these two oak species is known to take place $[22,30]$, predominantly so from $Q$. robur into $Q$. petraea $[3,30]$. Similarly, we note that a sizeable portion of $Q$. petraea trees cannot be differentiated from $Q$. robur trees, whereas $Q$. robur is much more homogeneous, suggesting introgression of $Q$. robur alleles into $Q$. petraea but not 
Table II. Spearman rank-order coefficients of correlation between traits ${ }^{1}$ ( 286 trees of both species and intermediate oaks).

\begin{tabular}{|c|c|c|c|c|c|c|c|c|c|c|c|}
\hline & $\begin{array}{l}\text { Ring } \\
\text { width }\end{array}$ & $\begin{array}{l}\text { 2-phenyl- } \\
\text { ethanol }\end{array}$ & $\begin{array}{l}\text { Panto- } \\
\text { lactone }\end{array}$ & Eugenol & $\begin{array}{c}\text { Mevalono- } \\
\text { lactone }\end{array}$ & Vanillin & $\begin{array}{l}\text { Syring- } \\
\text { aldehyde }\end{array}$ & $\begin{array}{l}\text { Conifer- } \\
\text { aldehyde }\end{array}$ & cis-WL & trans-WL & Total-WL \\
\hline 2-phenylethanol & -0.065 & & & & & & & & & & \\
\hline Pantolactone & 0.077 & 0.453 & & & & & & & & & \\
\hline Eugenol & 0.046 & 0.633 & 0.349 & & & & & & & & \\
\hline Mevalonolactone & -0.009 & -0.108 & 0.239 & -0.185 & & & & & & & \\
\hline Vanillin & -0.137 & 0.662 & 0.372 & 0.686 & -0.268 & & & & & & \\
\hline Syringaldehyde & -0.212 & 0.642 & 0.390 & 0.629 & -0.089 & 0.841 & & & & & \\
\hline Coniferaldehyde & -0.213 & 0.622 & 0.366 & 0.689 & -0.150 & 0.843 & 0.838 & & & & \\
\hline trans whisky-lactone & 0.219 & 0.129 & 0.006 & 0.274 & 0.041 & 0.007 & 0.077 & 0.109 & & & \\
\hline cis whisky-lactone & 0.167 & 0.078 & 0.010 & 0.259 & 0.108 & 0.010 & 0.077 & 0.117 & 0.843 & & \\
\hline Total whisky-lactone & 0.190 & 0.129 & 0.023 & 0.292 & 0.072 & 0.031 & 0.101 & 0.143 & 0.964 & 0.940 & \\
\hline cis-WL / total $\mathrm{WL}^{2}$ & 0.161 & 0.059 & -0.035 & 0.072 & -0.116 & -0.029 & -0.026 & -0.003 & 0.455 & -0.054 & 0.245 \\
\hline
\end{tabular}

${ }^{1}$ All values higher than 0.12 are significant at the 0.05 threshold.

${ }^{2}$ WL: whisky-lactone.

Table III. Test of spatial aggregation of wood volatile compounds (in $\mathrm{m})^{1}$.

\begin{tabular}{lccc}
\hline Volatile compounds & & Species & \\
\cline { 2 - 4 } & Both species (276 samples) & Q. petraea $(118$ samples) & Q. robur $(158$ samples) \\
\hline 2-phenylethanol & $\mathrm{NS}$ & $90 \mathrm{~m}$ & $\mathrm{NS}$ \\
Pantolactone & $\mathrm{NS}$ & $\mathrm{NS}$ & $\mathrm{NS}$ \\
Eugenol & $\mathrm{NS}$ & $\mathrm{NS}$ & $\mathrm{NS}$ \\
Mevalonolactone & $\mathrm{NS}$ & $\mathrm{NS}$ & $\mathrm{NS}$ \\
Vanillin & $\mathrm{NS}$ & $\mathrm{NS}$ & $\mathrm{NS}$ \\
Syringaldehyde & $\mathrm{NS}$ & $\mathrm{NS}$ & $\mathrm{NS}$ \\
Coniferaldehyde & $\mathrm{NS}$ & $\mathrm{NS}$ & $\mathrm{NS}$ \\
trans whisky-lactone & $105 \mathrm{~m}$ & $\mathrm{NS}$ & $\mathrm{NS}$ \\
cis whisky-lactone & $120 \mathrm{~m}$ & $110 \mathrm{~m}$ & $\mathrm{NS}$ \\
Total whisky-lactone & $125 \mathrm{~m}$ & $\mathrm{NS}$ & $\mathrm{NS}$ \\
Ratio cis-WL $/$ total WL & & \\
\hline
\end{tabular}

${ }^{1}$ NS: not significant; when a significant spatial structure is detected, the distance up to which trees' values are positively autocorrelated is provided.

${ }^{2}$ nc: not computed.

${ }^{3}$ WL: whisky-lactone.

the reverse. Further studies combining molecular markers are needed to evaluate this hypothesis.

Another remarkable observation is that trees that have high whisky-lactone content in their wood (mostly $Q$. petraea) have either high amount of cis or high amount of trans isomer, but not high amounts of both isomers. This suggests that the formation of each isomer is made at the expense of the formation of the other, implying that their synthesis is not independent, despite the fact that both isomers covary positively in the complete sample (i.e., when both species are included). So far, there is only limited information on the biosynthesis of these two isomers, although the immediate precursor of cis whisky- lactone has been identified [23,24]. Further analyses of their biosynthesis should help explain this pattern.

Our study fully confirms that the nature of the oak species has a major effect on wood volatiles. The role of these compounds remains elusive (repulsive effect against xylophagous insects?) and deserves specific investigations. However, for practical applications that depend on the aromatic properties of the wood (e.g. in cooperage), it is already advisable to control for botanical species, as much if not more so than for geographic origin. In contrast, ring width clearly appears to be of more dubious value for such purposes. In conclusion, rigorous monitoring and traceability of wood origin and especially of 


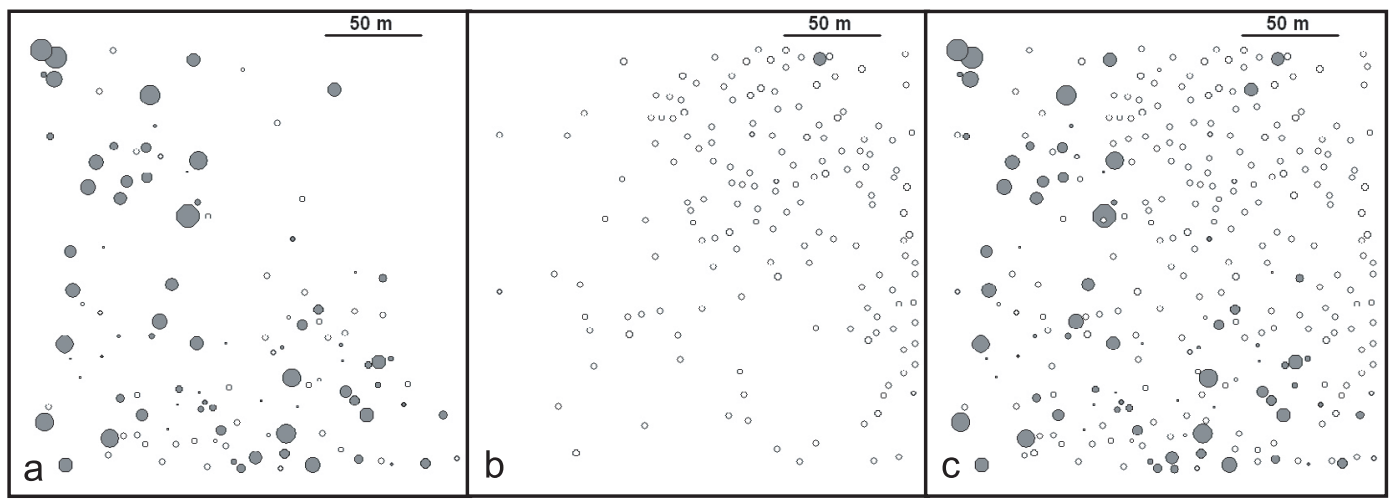

Figure 4. Spatial distribution of cis whisky-lactone content in each species. (a) Q. petraea, (b) Q. robur, (c) all individuals. Values above average in black, below average in white. Circle diameter is proportional to the deviation from the overall mean.
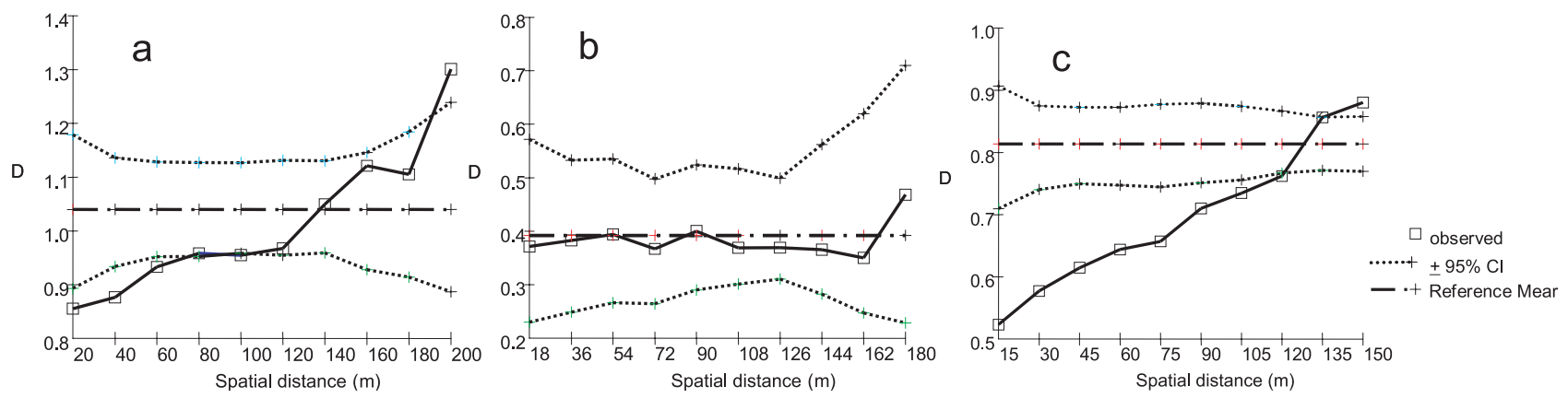

Figure 5. Distograms for cis whisky-lactone. (a) Q. petraea (118 samples), (b) Q. robur (158 samples), (c) all individuals.

species should allow coppers to better match his barrels to the profile of the wine or the brandy to be matured.

Acknowledgements: The authors thank Jean-Marc Louvet (INRA Bordeaux) for sample collection and André Perrin (LERFoB-Nancy) for sample preparation. The ONF services in La Petite Charnie State Forest, Le Mans, Orléans and Fontainebleau which organized the lumberyard and gave the logs. They have provided precious raw material and an unrivalled collection for research. We thank also JeanClaude Boulet (INRA Montpellier) for helpful advice.

\section{REFERENCES}

[1] Abbott N., Puech J.L., Bayonove C., Baumes R., Determination of the aroma threshold of the cis and trans racemic forms of $\beta$ methyl- $\gamma$-octalactone by gas chromatography-sniffing analysis, Am. J. Enol. Vitic. 496 (1995) 292-294.

[2] Bacilieri R., Ducousso A., Kremer A., Genetic, morphological, ecological and phenological differentiation between Quercus petraea (Matt) Liebl. and Quercus robur L. in a mixed stand of Northwest of France, Silvae Genet. 44 (1995) 1-10.

[3] Bacilieri R., Ducousso A., Petit R.J., Kremer A., Mating system and asymmetric hybridization in a mixed stand of European oaks, Evolution 50 (1996) 900-908.

[4] Bergès L., Chevalier R., Dumas Y., Franc A., Gilbert J.-M., Sessile oak (Quercus petraea Liebl.) site index variations in relation to climate, topography and soil in even-aged high-forest stands in northern France, Ann. For. Sci. 62 (2005) 391-402

[5] Boidron J.N., Chatonnet P., Pons M., Influence du bois sur certaines substances odorantes des vins, Connaiss. Vigne Vin 22 (1988) 275-294.
[6] Cadahia E., Muñoz L., Fernandez de Simon B., Garcia-Vallejo M.C., Changes in low molecular phenolic compounds in Spanish, French, and American oak woods during natural seasoning and toasting, J. Agric. Food Chem. 49 (2001) 1790-1798.

[7] Cantagrel R., Snakkers G., Quelques caractéristiques des merrains en fin de maturation en Charente. Variabilité rencontrée, différences entre tonnelleries, corrélations entre caractéristiques, Rev. Enol. 84 (1997) 7-13.

[8] Chatonnet P., Influence des procédés de tonnellerie et des conditions d'élevage sur la composition et la qualité des vins élevés en fûts de chêne, Thèse, Univ. Bordeaux II, 1995, p. 268.

[9] Chatonnet P., Boidron J.N., Dubourdieu D., Pons M., Évolution de certains composés volatils du bois de chêne au cours de son séchage, J. Vigne Vin 28 (1994) 359-380.

[10] Cutzach I., Chatonnet P., Henry R., Dubourdieu D., Identification of volatile compound with a "toasty" aroma in heated oak used in barrelmaking, J. Agric. Food. Chem. 45 (1997) 2217-2224.

[11] Degen B., Petit R., Kremer A., SGS - spatial genetic software: a computer program for analysis of spatial genetic and phenotypic structures of individuals and populations, J. Heredity 92 (2001) 447-448.

[12] Deichsel G., Trampisch H.J., Clusteranalyse und Diskriminanzanalyse, Gustav Fischer, Verlag, Stuttgart, 1985.

[13] Díaz-Maroto I., Vila-Lameiro P., Silva-Pando F., Autoécologie des chênaies de Quercus robur L. en Galice (Espagne), Ann. For. Sci. 62 (2005) 737-749.

[14] Doussot F., Pardon P., Dedier J., De Jeso B., Individual, species and geographical origin influence on cooperage oak extractible content (Quercus robur L. and Quercus petraea Liebl.), Analusis 28 (2000) 960-965. 
[15] Doussot F., Variabilité des teneurs en extractibles des chênes sessiles (Quercus petraea Liebl.) et pédonculé (Quercus robur L.) Influence sur l'élevage des vins, Thèse, Univ. Bordeaux I, 2000, $360 \mathrm{p}$.

[16] Fernandez de Simon B., Cadahia E., Conde E., Garcia-Vallejo M.C., Evolution of phenolic compounds of Spanish oak wood during natural seasoning. First results, J. Agric. Food Chem. 47 (1999) 1687-1694.

[17] Feuillat F., Huber F., Keller R., Mise au point sur: la notion de grain utilisée pour le classement des merrains de chêne, Rev. Fr. Enol. 139 (1992) 65-69.

[18] Feuillat F., Keller R., Variability of oak wood (Quercus robur L., Quercus petraea Liebl.) anatomy relating to cask properties, Am. J. Enol. Vitic. 48 (1997) 502-508.

[19] Francis I., Sefton M., Williams P., A study by sensory descriptive analysis of the effects of oak origin, seasoning and heating on the aromas of oak model wine extracts, Am. J. Enol. Vitic. 43 (1992) $23-30$.

[20] Haneca K., Van Acker, J., Beckman H., Growth trends reveal the forest structure during Roman and Medieval times in Western Europe: a comparison between archaeological and actual oak ring series (Quercus robur and Quercus petraea), Ann. For. Sci. 62 (2005) 797-805.

[21] Haslam E., Shikimic acid. Metabolism and metabolites, John Willey and Sons, Chichester, 1993, 387 p.

[22] Lexer C., Kremer A., Petit R.J., Shared alleles in sympatric oaks: recurrent gene flow is a more parsimonious explanation than ancestral polymorphism, Mol. Ecol. 15 (2006) 2007-2012.

[23] Masson E., Baumes R., Le Guernevé C., Puech J.-L., Identification of a precursor of $\beta$-methyl- $\gamma$-octalactone in the wood of sessile oak, J. Agric. Food Chem. 48 (2000) 4306-4309.

[24] Masson E., Baumes R., Puech J.-L., Comparison of direct and indirect methods of measuring precursor of $\beta$-methyl- $\gamma$-octalactone and their application to the analysis of sessile oak wood [Ouercus petraea (Matt.) Liebl.], J. Chromatogr. A 905 (2001) 183-191.

[25] Mosedale J.R., Charrier B., Janin G., Genetic control of wood colour, density and heartwood ellagitannin concentration in European oak (Quercus petraea and Quercus robur), Forestry 69 (1996) 111-124.

[26] Mosedale J.R., Ford A., Variation of the flavour and extractives of European oak wood from two French forests, J. Sci. Food Agric. 70 (1996) 273-287.
[27] Mosedale J.R., Savill P.S., Variation of heartwood phenolics and oak lactones between the species and phenological types of Quercus petraea and Q. robur, Forestry 69 (1996) 47-55.

[28] Mosedale J.R., Feuillat F., Baumes R., Dupouey J.L., Puech J.L., Variability of wood extractives among Quercus robur and Quercus petraea trees from mixed stands and their relation to wood anatomy and leaf morphology, Can. J. For. Res. 28 (1998) 1-13.

[29] Mosedale J.R., Feuillat F., Baumes R., Dupouey J.L., Keller R., Puech J.L., La qualité du bois des chênes de Cîteaux pour la tonnellerie. $2^{\mathrm{e}}$ partie: Composition en extractibles du bois en liaison avec l'espèce (chêne rouvre, chêne pédonculé). Corrélations avec la morphologie foliaire et l'anatomie du bois, Rev. Fr. Enol. 187 (2001) 30-33.

[30] Petit R.J., Bodénès C., Ducousso A., Roussel G., Kremer A., Hybridization as a mechanism of invasion in oaks, New Phytol. 161 (2003) 151-164.

[31] Prida A., Boulet J.C., Nepveu G., Puech J.-L., The effect of the species and ecological conditions on ellagitannin content in wood of oaks from an evenaged and mixed (Quercus robur L., Quercus petraea Liebl.) stand, Ann. For. Sci. 63 (2006) 415-424.

[32] Rozas V., Dendrochronology of pedunculate oak (Quercus robur L.) in an old-growth pollarded woodland in northern Spain: establishment patterns and the management history, Ann. For. Sci. 62 (2005) $13-22$

[33] Rozas V., Dendrochronology of pedunculate oak (Quercus robur L.) in an old-growth pollarded woodland in northern Spain: tree-ring growth responses to climate, Ann. For. Sci. 62 (2005) 209-218.

[34] Sefton M., Francis I., Pocock K., Williams P., The influence of natural seasoning on the concentrations of eugenol, vanillin, and cis- and trans- $\beta$-methyl- $\gamma$-octalactone extracted from French and American oak wood, Sci. Alim. 13 (1993) 629-643.

[35] Snakkers G., Nepveu G., Guilley E., Cantagrel R., Variabilités géographique, sylvicole et individuelle de la teneur en extractibles de chênes sessiles français (Quercus petraea Liebl.) : polyphénols, octalactones et phénols volatils, Ann. Sci. For. 57 (2000) 251-260.

[36] Vivas N., The notion of grain in cooperage, J. Sci. Tech. Tonnellerie, 1 (1995) 17-32.

[37] Vivas N., Abasalon C., Benost F., Vitry C., Grazillier S., de Revel G., Bertrand A., Les chênes européens $Q$. robur L. et $Q$. petraea (Matt.), Liebl.: Analyse des potentialités œnologiques des différents massifs forestiers, $5^{\mathrm{e}}$ Colloque Sci. Techn. Tonnellerie, Bordeaux, 2000, pp. 31-37. 